DOI https://doi.org/10.30525/978-9934-588-90-7-69

\title{
САМОМОНИТОРИНГ КАК ВАЖНАЯ СОСТАВЛЯЮЩАЯ УСПЕШНОГО КОММУНИКАТИВНОГО ПОВЕДЕНИЯ БУДУЩИХ СПЕЦИАЛИСТОВ
}

\author{
Завалевская Е. В. \\ кандидат педагогических наук, \\ заведующая кафедрой лингвистической подготовки
}

Веретенникова В. П.

старший преподаватель кафедры лингвистической подготовки Одесская национальная академия связи имени А. С. Попова г. Одесса, Украина

Развитие современного общества в сфере образования оказывает большое влияние на процесс иноязычной подготовки в неязыковом вузе. Значимым фактором социальной и профессиональной адаптации будущого специалиста сегодня является владение одним или несколькими иностранными языками, что является, в свою очередь, неотъемлемым показателем его общей культуры. Иностранный язык, как известно, входит в число ключевых компетенций специалиста новой формации, способного к саморазвитию и ориентированного на межкультурный диалог.

В связи с этим, актуальное значение приобретает подготовка высококвалифицированных специалистов, формирование их профессиональной мобильности, самосовершенствования, повышение мотивации к учебной деятельности, а также формирования профессионального самосознания. Проблемой теории профессионального самосознания будущих специалистов занимались такие ученые, как В. Волкова, А. Мисечко, Л. Пидкаминная, И. Стотика, А. Стотика, Т. Титаренко, Ф. Фуллер, П. Завир и др.

Психологическая литература определяет осознание себя как философское осмысление себя и своего развития с точки зрения новых принципов и новых подходов к самоидентификации и самоопределения [1].

Одной из приоритетных целей образования является необходимость создания и поддержания психологических условий, обеспечивающих полноценное личностное развитие студентов. Основой личностно-развивающегося подхода в образовании становятся концепции субъектности личности, которые рассматривают механизмы реализации возможностей человека, как источника творческой и нравственной активности (С. Рубинштейн, А. Брушлинский, Е. Волкова, В. Петровский и др.). До 
настоящего времени, однако, идея субъектности не получила должного распространения в теории и практике иноязычного образования. Мы считаем, что субъектный подход является очень продуктивным при решении проблем иноязычного образования, обусловленных личностными, а именно мотивационными и смысловыми, препятствиями в обучении иностранному языку.

Профессиональное самосознание следует трактовать как осознание себя в профессиональной деятельности, оценка себя как специалиста (удовлетворение или неудовлетворение результатами своей профессиональной деятельности), а также построения своего поведения, действий в решении профессиональных задач [2]. Исходя из этого, профессиональное самосознание - это сложное интегративное профессиональноличностное образование, которое предусматривает оценку себя как специалиста: комплекс представлений о себе, своих действий, норм, моделей поведения в решении задач, согласно требованиям профессиональной деятельности.

По нашему мнению, субъектность как мера активации в овладении иностранным языком может развиваться только в условиях длительного самомониторинга, благодаря чему осознаются сильные и слабые стороны собственной познавательной деятельности с целью повышения учебных результатов.

Самомониторинг (self-monitoring) - это процесс, посредством которого студент узнаёт о своей самопрезентации и регулирует её так, чтобы она соответветствовала требованиям определённых социальных ситуаций. Термин «самомониторинг» впервые использовал американський психолог М. Снайдер для обозначения способности человека демонстрировать такой образ, который был бы приятен окружающим [3]. Используя длительный мониторинг можно сконструировать модель развития субъектности студентов в обучении иностранному языку в неязыковом вузе, т.е. активизировать рефлексивные процессы и на этой основе развивать субъектность личности как детерминанты в овладении иностранным языком. Человек, осуществляющий самомониторинг, отдаёт себе отчёт в том, что он говорит, кому говорит, как говорит и к каким это может привести последствиям. То есть, говорящий контролирует своё общение в различных коммуникативных ситуациях и хорошо понимает, каких тем ему лучше не касаться в обсуждении. При возникновении неприятной ситуации он может мысленно принять решение, как ему поступать дальше. Он может ответить грубо и таким образом спровоцировать конфликт или сдержаться и тем самым избежать неприятой ситуации. Такую способность осознавать и контролировать свои действия по ходу 
разговора О. Матьяш называет составляющей коммуникативной компетентности [4, с. 128]

Основными объектами мониторинга в учебной деятельности могут выступить: сама учебно-познавательная деятельность студента (ее характеристики, структура), которая включает деятельность по самоподготовке; психическое развитие личности и формирование новообразований учебной деятельности; развитие общения; профессиональная деятельность личности. Субъектность личности как детерминанта успешности овладения иностранным языком будет возможной в том случае, если процесс обучения будет представлять собой учение со следующими характеристиками: мотивированность, вовлечённость, рефлексивность, организованность и самоконтроль. Считаем, что развитие субъектности личности в овладении иностранным языком следует осуществлять на основе философии и психологии гуманизма, научного подхода к развитию личности студента, а также методики технологий стимулирования рефлексивных процессов в обучении. Рефлексивно-творческое обучение студента должно быть направлено на самопознание, самосознание, а также его творческую самореализацию. Исходя из этого, процесс обучения должен предполагать самомониторинг студентов, который может проявляться в разных формах их учебной деятельности. С этой целью можно разработать так называемый Портфель студента (portfolio), который будет способствовать формированию необходимых навыков рефлексии, т.е. самонаблюдению [5].

В процессе обучения иностранному языку мы часто используем эту инновационную технологию как альтернативную форму контроля, что позволяет получить динамическую картину учебного и языкового развития студентов. Языковый портфель - это своего рода «зеркало» [6, с. 105] процесса изучения иностранного языка. Посредством рефлексивной самооценки студентов в нём отражаются главные компоненты этого процесса, создающие необходимые условия для развития их учебной компетенции и автономии. По собственному выбору или по заданию преподавателя студент отбирает в свой портфолио выполненные им работы (контрольные работы, тесты, сочинения, домашние задания, рефераты, доклады и т.п.). Отбор проводится в течение одного года или всех лет изучения иностранного языка. Ключевыми элементами становятся рефлексия изучающего язык и самомониторинг. Главным в такой работе является самооценка студента, приём в виде аргументации, обоснования и рассуждения. Для того, чтобы самоконтроль стал неотьемлемой частью обучения иностранному языку в вузе, с самого первого занятия следует помочь студентам задуматься о своей успеваемости, проблемах и путях их решения, о роли самоконтроля в 
организации полноценной обратной связи. Студент должен систематически отслеживать результаты своей деятельности и отбирать наиболее интересные, с его точки зрения, работы в свой портфолио. Он должен тщательно анализировать эти работы, если необходимо, внести коррективы, дать объяснения, т.е. самооценить себя: что ему удалось, а что нет, почему не удалось и на что следует обратить внимание. Студент также может выразить своё мнение относительно оценки преподавателя. Такие аргументы, суждения составляют сущность рефлексии, что позволяет студентам привнести осмысленное представление о собственном учении и увеличивают возможности установления диалога между студентом и преподавателем относительно целей учебного курса и успеваемости. Например, мы предложили студентам экспериментальной группы вести дневники самонаблюдения, при этом они должны были следовать такому алгоритму самомониторинга, который заключался в анализе собственного мотивационного состояния. Если перед студентами была поставлена цель, и одновременно было другое желание, которое находилось в противоречии с целью, им следовало ответить на следующие вопросы: хочу достичь поставленной цели? хочется мне заниматься этим прямо сейчас? что мне хочется делать сейчас? как это объединить с тем, что я решил (а) сделать?

Кроме того, при помощи языкового портфеля преподаватель иностранного языка может также отслеживать собственные успехи в области методики преподавания и языкового самосовершенствования.

\section{Литература:}

1. Ребер Артур. Большой толковый психологический словарь. Том 2 (П-Я): Пер. с англ. М. : Вече, АСТ, 2000. 560 с.

2. Гончаренко С.У. Український педагогічний словник. К.: Либідь, 1997. $375 \mathrm{c}$.

3. Snyder M. Self-monitoring of expressive behavior. Journal of Personality and Social Psychology. 1974. Vol. 30. P. 526-537.

4. Межличностная коммуникация: теория и жизнь / О. И. Матьяш, В. М. Погольша, Н. В. Казаринова и др.; науч. ред. О. И. Матьяш. СПБ. : речь, 2011. $560 \mathrm{c}$.

5. Гальскова Н.Д. Языковый портфель как инструмент оценки учащегося в области изучения иностранных языков. Иностранные языки в школе. 2000. № 5. С. 6-11.

6. Коряковцева Н.Ф. Современная методика организации самостоятельной работы изучающих иностранный язык. М.: Аркти, 2002. 176 с.

7. Пейн С. Дж. Учебное портфолио - новая форма контроля и оценки достижений учащихся. Директор школы. 2000. № 1. С. 65-67. 